Journal of Epidemiology and Public Health (2018), 3(1): 60-71

https://doi.org/10.26911/jepublichealth.2018.03.01.05

\title{
Factors Associated with Safe Sex Behavior Among Commercial Sex Workers in Banjarsari, Surakarta, Central Java
}

\author{
Maecelina Hestin Ambarsari1), Argyo Demartoto²), C.S.P Wekadigunawan3) \\ 1) Masters Program in Public Health, Universitas Sebelas Maret \\ 2) Faculty of Social and Political Sciences, Universitas Sebelas Maret \\ 3) Faculty of Medicine, Universitas Sebelas Maret
}

\begin{abstract}
Background: It is estimated that more than one millionpeople in the world contract sexuallytransmitted disease everyday. Annually approximately 357 million new infections occur by one of four sexually-transmitted diseases: chlamidia, gonorrhea, syphilis, and mouth ulcer. To date HIV/AIDS has spread in 407 of 507 districts and municipalities in Indonesia, or equivalently covering $80 \%$ districts and municipalities of the country. In Surakarta, the cumulative incidence of HIV/AIDS from 2005 to 2017 was 561 cases, with 38 HIV cases and 46 AIDS cases in 2017 alone. The incidence of HIV/AIDS has been increasing year by year. This study aimed to examine factors associated with safe sex behavior among commercial sex workers in Banjarsari, Surakarta, Central Java.

Subjects and Method: Thiswas an analytic observational study with cross-sectional design.The study was conducted in Banjarsari Sub-district, Surakarta, Central Java. A total sample of 100 commercial sex workers was selected by stratified random sampling. The dependent variable was safe sex behavior. The independent variables were knowledge of infectious transmitted disease and HIV/AIDS, self efficacy,condoms availability, access to health care service, health personnel support, and peer support. The data were collected by questionnaire and analyzed by multiple linear regression.

Results:Safe sex behavior was associated with good knowledge of sexually-transmitted disease and HIV/AIDS $(b=0.19 ; 95 \% \mathrm{CI}=0.01$ to $0.30 ; \mathrm{p}=0.032)$, strong self efficacy $(\mathrm{b}=0.18 ; 95 \% \mathrm{CI}=0.01$ to $0.38 ; \mathrm{p}=0.047)$, condoms availability $(\mathrm{b}=0.30 ; 95 \% \mathrm{CI}=0.36$ to $1.20 ; \mathrm{p}<0.001)$, good access to health care service $(b=0.19 ; 95 \% C I=0.02$ to $0.52 ; p=0.035)$, strong health personnel support $(\mathrm{b}=0.18 ; 95 \% \mathrm{CI}=0.01$ to $0.57 ; \mathrm{p}=0.041)$, strong peer support $(\mathrm{b}=0.17 ; 95 \% \mathrm{CI}=0.01$ to 0.50 ; $\mathrm{p}=0.046)$.

Conclusion:Safe sex behavior is associated with good knowledge of sexually-transmitted disease and HIV/AIDS, strong self efficacy, condoms availability, access to health care service, strong health personnel support, strong peer support.
\end{abstract}

Keyword:safe sex behavior, knowledge, self efficacy, condoms availability, access to health service, health personnel support, peer support

\section{Correspondence:}

Maecelina Hestin Ambarsari. Masters Program in Public Heath, Universitas Sebelas Maret,Jl. Ir. Sutami 36 A, Surakarta 57126, Central Java. Email: hestinmaecelina@gmail.com.

Mobile: +6285742975078 .

\section{BACKGROUND}

One of the purposes of Sustainable Development Goals (SDGs) is to stop the epidemics of AIDS, Tuberculosis, Malaria, Neglected Tropical Diseases, Hepatitis, and water-borne diseases. In the Ministry of
Health regulation Number 21 of 2013, the HIV/AIDS transmission in Indonesia can be prevented by implementing $\mathrm{ABCD}$, namely abstinensia (do not do sexual activities before marriage), be faithful (be faithful to the spouse), condoms use 
(always use condoms when doing risky sex), no drug (do not consume drugs injection), and education (informing our close ones about the knowledge of HIV).

In fact, more than a milion people are infected by Sexually Transmitted Diseases each day all over the world. Each year, there are about 357 millions new infections with one out of four Sexually Transmitted Diseases, namely chlamydia, gonorrhea, syphilis and mouth ulcre (WHO, 2016). In 2015, it is predicted that there will be 36,7 millions people infected by HIV. It increased for about 3.4 millions compared to the ones in 2010. There are 2.1 millions among them which belong to recent HIV cases (Ministry of Health, 2016).

In Indonesia, up to now, HIV/AIDS has been spread throughout 407 out of 507 regencies/cities covering $80 \%$ of area in Indonesia. The government cooperates with some local and foreign institutions as an effort to prevent HIV/AIDS spreading wider. The number of HIV infections from October up to December 2016 is reported to be approximately 13.287. Meanwhile, the number of AIDS cases from October up to December 2016 is reported to be about 3812 (Spiritia, 2017). The pattern of HIV transmission based on the risk factor does not change in the last five years. Mostly, HIV/AIDS infects heterosexuals for about 67.6\%, followed by injection Napza (addictive drugs) consumers for about $10.9 \%$ and homosexuals for about $3.3 \%$ (Ministry of Health, 2016).

In 2016, in Central Java, the number of syphilis cases is 1206, meaning that it increases compared to that in 2014 which was about 907 cases. Meanwhile, there are 2763 recent HIV/AIDS cases meaning that it inreases compared to the same period in 2014 which was about 2480 (Local Goverment of health, Central Java, 2015).
Based on the preliminary study in Surakarta, there were 563 female commercial sex workers. According to the AIDS Eradication Commission of Surakarta, there were 561 cases from 20052017, with the recent HIV cases for about 38 and AIDS cases for about 46 cases in 2017. The statistics shows that it increases from year to year. It mostly infects heterosexuals including the female commercial sex workers.

Based on the Ministry of Health regulation Number 21 of 2013, it is stated that the safe sex behavior needs to be implemented by female commercial sex workers because they have high risks of being infected by Sexually Transmitted Diseases or HIV/AIDS. Female commercial sex workers are those who provide services in order to get money and they are considered as the transmitters of HIV/AIDS and other sexually transmitted diseases. Commercial sex customers are one of the causes of the Sexually Transmitted Diseases or HIV/AIDS transmissions when having sexual activity without condoms (Nyagero et al, 2012). The behavior is influenced by several factors as stated by Lawrence Green, namelypredisposing, enabling, dan reinforcingfactors.

The change of behavior and factors related to female commercial sex workers are the sociodemographic factors including, age, educational background, religion, marital status, the number of children, how long they have become commercial sex workers, the knowledge about HIV/AIDS, other alternative jobs, not using/using condoms inconsistently (Nyagero et al 2012). Meanwhile, according toRitcher (2013) in his study about characteristics, sexual behaviors and access to the health service for sex workers in South Africa, it is stated that female commercial sex workers implemented more safe sex behavior 
compared to transgenders or male commercial sex workers. The sexual behavior was in the form of the access to health service and the use of condoms.

Based on the background presented above, the studyer conducted a study about the factors influencing the safe sexual behavior of female commercial sex workers.

\section{Study design}

\section{SUBJECTS AND METHOD}

This was an analytic observational study with a cross-sectional design. The study was conducted in Banjarsari district, Surakarta, Central Java, in November 2017.

\section{Population and sample}

This study employed all of female commercial sex workers in Banjarsari district as the population. The samples were taken using stratified random sampling.

Inclusion criteria in this study were female commercial sex workers in Banjarsari district who were willing to participate. The exclusion criteria were female commercial sex workers who drew back before the study was even conducted and those who were not in the place where the study was conducted.

\section{Study variables}

The dependent variable was the safe sex behavior. The independent variables were the knowledge about sexually transmitted diseases and HIV/AIDS, self efficacy, condoms availability, health personnel supports, and peer supports.

\section{Study variables}

Sexually Transmitted Diseases and HIV/AIDS was defined as the result of learning the knowledge and information about Sexually Transmitted Diseases and HIV/AIDS.
Self-efficacy was defined as the belief or ability of the female commercial sex workers to implement safe sex behavior.

Condoms availability was defined as whether or not condoms are available in the surroundings of the workers.

Access to health services was defined as how difficult it is to get the location or how the health service facilities are reachable.

Health personnel supports was defined as the positive attitude from the personell in supporting the implementation of safe sex behavior.

Peer support was defined as a positive attitude of their friends who are also commercial sex workers in the implementation of safe sex behavior.

Safe sex behavior was defined as an action of female commercial sex workers to prevent Sexually transmitted diseases and HIV/AIDS.

\section{Data analysis}

The data were collected using questionnaires. The questionnaires have passed the validity and reliability tests.

The data were analysed using univariate, bivariate and multivariate analyses. Univariate analysis was to know the characteristics of study subjects. Bivariate analysis used pearson product moment correlation and multivariate analysis used linear regression analysis.

\section{Research Ethics}

The research ethical clearance was obtained from the Research Ethics Committee at Dr. Moewardi Hospital, Surakarta, Central Java, Indonesia. Research ethics included issues such as informed consent, anonimity, confidentiality, and ethical clearance. 
Table 1.The Result of Reliability Test

\begin{tabular}{lcc}
\hline \multicolumn{1}{c}{ Variable } & Item Total Correlation (r) & Alpha Cronbach \\
\hline The knowledge of Sexually & $\geq 0.22$ & 0.70 \\
Transmitted Diseases and HIV/AIDS & $\geq 0.31$ & \\
Self-Efficacy & $\geq 0.31$ & 0.71 \\
Condoms availability & $\geq 0.24$ & 0.70 \\
Access to health services & $\geq 0.21$ & 0.72 \\
Health personnel supports & $\geq 0.30$ & 0.70 \\
Peer's supports & $\geq 0.32$ & 0.70 \\
Safe sex behavior & & 0.71 \\
\hline
\end{tabular}

Based on the reliability test of itemtotal correlation, the measurement of the knowledge about HIV/AIDS, self-efficacy, condoms availability, access to health services, health personnel supports, peer support variables was $\mathrm{r}$ arithmatic $\geq 0.20$, and Cronbach's Alpha $\geq 0.70$, so all the items are proven to be reliable. The result of questionnaire reliability test is presented in Table 1.

\begin{tabular}{l}
\hline RESULTS \\
\hline Based on Table 2, there were 82 female \\
commercial sex workers who were aged 20- \\
45 years old (82\%). As many as 53 study \\
subjects (53\%) were attained junior high \\
school. As many as 50 study subjects (50\%) \\
were divorced women and 3 study subjects \\
(3\%) were married or living with husband.
\end{tabular}

Table 2.The Characteristics of Study Subjects

\begin{tabular}{lll}
\hline \multicolumn{1}{c}{ Characteristics } & N & \% \\
\hline $\begin{array}{l}\text { Age } \\
\text { <20 years old }\end{array}$ & 1 & 1 \\
20-45 years old & 82 & 82 \\
$\begin{array}{l}\text { 46-60 years old } \\
\text { Education }\end{array}$ & 17 & 17 \\
Do not attend any formal school & 5 & 5 \\
Elementary School Graduates & 37 & 37 \\
Junior High School Graduates & 53 & 53 \\
Senior High School Graduates & 5 & 5 \\
Marital Status & 11 & 11 \\
Single & 3 & 3 \\
Married and living together & 15 & 15 \\
Married and not living together & 50 & 50 \\
Divorced but the ex husband is still alive & 21 & 21 \\
Divorces because the husband has passed away & & \\
\hline
\end{tabular}

Table 3. The Descriptions of Study Variable

\begin{tabular}{lcllll}
\hline \multicolumn{1}{c}{ Variables } & N & Min. & Max. & Mean & Deviation standard \\
\hline The knowledge of Sexually Transmitted & 100 & 3 & 14 & 10.61 & 1.99 \\
Diseases and HIV/AIDS & & & & & \\
Self-efficacy & 100 & 2 & 9 & 5.98 & 1.62 \\
Condoms availability & 100 & 1 & 4 & 3.29 & 0.65 \\
Access to health services & 100 & 1 & 5 & 3.71 & 1.17 \\
Medical personnel supports & 100 & 1 & 5 & 3.72 & 1.05 \\
Peer's supports & 100 & 1 & 6 & 4.53 & 1.15 \\
Safe sex behavior & 100 & 1 & 9 & 6.5 & 1.68 \\
\hline
\end{tabular}

Table 3 is the descriptive statistics of each variable, namely minimum score, maxi- mum score, mean, and deviation standard. The table above is to measure the variable 
Journal of Epidemiology and Public Health (2018), 3(1): 60-71

https://doi.org/10.26911/jepublichealth.2018.03.01.05

using continuous scale, both the dependent and independent variables. Mean score displays the average score, meanwhile deviation standard presents how varied the data are. If the standard deviation score is low, the data can be categorized as representative.

Table 4. Bivariate Analysis of product moment Pearson Correlation

\begin{tabular}{lcll}
\multicolumn{1}{c}{ Independent Variabels } & & r & p \\
The knowledge of Sexually Transmitted Diseases & 0.38 & & $<0.001$ \\
and HIV/AIDS & & $<0.001$ \\
Self-efficacy & 0.36 & 0.001 \\
Condoms availability & 0.32 & 0.001 \\
Access to health services & 0.31 & 0.001 \\
Health personnel supports & 0.32 & $<0.001$ \\
Peer supports & 0.36 & & \\
\hline
\end{tabular}

Table 4 shows that the knowledge of Sexually Transmitted Diseases and HIV/AIDS was good $(\mathrm{r}=0.38, \mathrm{p}<0.001)$, the self-efficacy was strong $(r=0.36$, $\mathrm{p}<0.001)$, condoms availability was $(\mathrm{r}=$ $0.32, \mathrm{p}=0.001$ ), access to health services was $(\mathrm{r}=0.31, \mathrm{p}=0.001)$, health personnel

Table5.Linear Regression Analysis of Factors related to the safe sex behavior of Female Commercial Sex Workers

\begin{tabular}{|c|c|c|c|c|c|}
\hline \multirow[b]{2}{*}{$\begin{array}{l}\text { Independent } \\
\text { Variables }\end{array}$} & \multirow{2}{*}{$\begin{array}{c}\text { Unstandarized } \\
\text { path coefficients } \\
\text { (b) }\end{array}$} & \multirow{2}{*}{$\begin{array}{c}\text { Standarized } \\
\text { path } \\
\text { coefficients }(\beta)\end{array}$} & \multicolumn{2}{|c|}{ CI 95\% } & \multirow[b]{2}{*}{$\mathbf{p}$} \\
\hline & & & $\begin{array}{l}\text { Lower } \\
\text { Limit }\end{array}$ & $\begin{array}{l}\text { Upper } \\
\text { Limit }\end{array}$ & \\
\hline $\begin{array}{l}\text { The knowledge of } \\
\text { Sexually Transmitted }\end{array}$ & 0.16 & 0.19 & 0.01 & 0.30 & 0.032 \\
\hline Diseases and HIV/AIDS & & & & & \\
\hline Self-efficacy & 0.19 & 0.18 & 0.00 & 0.38 & 0.047 \\
\hline Condoms availability & 0.78 & 0.30 & 0.36 & 1.20 & 0.000 \\
\hline Access to health services & 0.27 & 0.19 & 0.02 & 0.52 & 0.035 \\
\hline $\begin{array}{l}\text { Health personnel } \\
\text { supports }\end{array}$ & 0.29 & 0.18 & 0.01 & 0.57 & 0.041 \\
\hline Peer supports & 0.25 & 0.17 & 0.00 & 0.50 & 0.046 \\
\hline
\end{tabular}

It can be seen in Table 5 that safe sex behavior has a relation to the knowledge of Sexually Transmitted Diseases and HIV/ AIDS, self-efficacy, condoms availability, a good access to health service, health personnel supports and peer supports.

Every improvement of one score unit about the knowledge of sexually transmitted diseases and HIV/AIDS improves the score of safe sex behavior by 0.16 unit ( $b=0.19$; CI 95\% $=0.01$ to $0.30, p=0.032$ ).

Every improvement of one score unit aboutthe self-efficacy improves the score of supports was $(\mathrm{r}=0.32, \mathrm{p}=0.001)$, peer's supports was $(\mathrm{r}=0.36, \mathrm{p}<0.001)$, which means that they have a positive relation with the safe sex behavior of female commercial sex workers and statistically is proven to be significant. safe sex behavior by 0.19 unit $(b=0.18$; CI $95 \%=0.00$ to $0.38, \mathrm{p}=0.047$ ).

Every improvement of one score unit aboutthe condoms availability improves the score of safe sex behavior by 0.78 unit $(b=0.30$; CI 95\% = 0.36 to $1.20, p<0.001$ ).

Every improvement of one score unit aboutthe access to health services improves the score of safe sex behavior by aman 0.27 unit $(\mathrm{b}=0.19$; CI $95 \%=0.02$ to $0.52, \mathrm{p}=$ 0.035).

Every improvement of one score unit aboutthe health personnel supports 
improves the score of safe sex behavior byo.28 unit ( $b=0.18$; CI $95 \%=0.01$ to 0.56 , $\mathrm{p}=0.041)$.

Every improvement of one score unit aboutthe peer's supports improves the score of safe sex behavior by 0.25 unit ( $b=0.17 ; 95 \%$ CI <0.01 to 0.50, $\mathrm{p}=0.046$ ).

\section{DISCUSSIONS}

a. The Relationship between Knowledge of Sexually Transmitted Diseases and HIV/AIDS and the Safe Sex Behavior

There is a positive relation between the knowledge of sexually transmitted diseases and HIV/AIDS and the safe sex behavior of the female commercial sex workers and the relation/effect is statistically significant $(b=0.19$; CI 95\%=0.01 to $0.30, p=0.032)$. Ford et al. (2000) conducted a study which also employed cross sectional approach and questionnaires as the instruments to collect data. The results showed that the knowledge of the workers has a significant relation to the use of condoms as the use of condoms is one of the ways to implement safe sex behavior in order not to be infected by HIV. By using condoms consistently, the transmission of sexually transmitted diseases and HIV/AIDS can be decreased.

Added to that, a study using the same method was conducted by Budiman et al. (2008) and the results show that there is a relation between the knowledge of female commercial sex workers and how they work in relation to prevent them being infected by sexually transmitted diseases and HIV/AIDS. The Chi square score waso.05 and $\mathrm{p}=0.032$. Educational background is an important factor that can be the parameter of someone's knowledge. It means that the better the knowledge, the safer the sex behavior to prevent the sexually transmitted diseases and HIV/AIDS. The knowledge is not only obtained from formal education, but it can also be obtained through mass and electronics media such as internet or from some counselings or conferences discussing about it.

Nyagero et al. (2012) combined the theories of Health Belief Model andTheory Planned Behavior. They further explained that one of the factors related to the behavior change of female commercial sex workers was their knowledge about HIV. They stated that someone who has good knowledge about it tends to have a better behavior.

Utami et al. (2016) implemented accidental sampling method in their study which the result showed that knowledge is an important factor which forms someone's behavior. It means that knowledge can be the initial motivation to behave well. The better someone knows about the importance of using condoms as an effort to prevent HIV/AIDS, the more consistent she will use condoms when having sex.

Sirait et al. (2013) conducted a study using consecutive sampling, bivariate testusing Chi Square and multivariateusing logistic regression which showed the significant relation between the knowledge of someone and the use of condoms in sexual activities. Based on PRECEDE PROCEED theory, it is stated that knowledge is categorized as predisposing factor that affects the subjects (female commercial sex workers). So, it prevents them from being infected by sexually transmitted diseases and increases their life expectancy.

Budiono (2012) conducted a study involving 140 female commercial sex workers stating that their knowledge is a significant factor which significantly affect the use of condoms in their sexual activities. 
Journal of Epidemiology and Public Health (2018), 3(1): 60-71

https://doi.org/10.26911/jepublichealth.2018.03.01.05

\section{b. The relation of self-efficacy with safe sexual behavior}

There is a positive relationship between self-efficacy and safe sexual behavior in female commercial sex workers and the effect is statistically significant $(b=0.18$; $95 \% \mathrm{CI}<0.01$ to $0.38, \mathrm{p}=0.047$ ). This is in line with the result of the study conducted by Widodo (2009) using explanatory study with quantitative and qualitative approaches. He stated that the higher the self-esteem in the prevention of sexually transmitted diseases and HIV/AIDS, the better the practice will be in the implementation of safe sexual behavior to prevent sexually transmitted diseases and HIV/AIDS.

This is also in line with the studyconducted by Wulandari et al. (2016) using Health Belief Model theory, the design and method of this study showed a similar result that there is a relation of selfefficacy with the sexually transmitted diseases prevention behavior significantly. Female commercial sex workers (FCSW) with strong self-efficacy have7.32 times greater to have healthy behaviors in sexually transmitted diseases prevention $(\mathrm{OR}=7.32 ; 95 \% \mathrm{CI}=1.83$ to $29.29 ; \mathrm{p}=$ $0.050)$.

Study from Sirait et al. (2013), using Health Belief Model theory, which stated that the ship crew (TSC) who have high self-ability will use condoms wisely (39.6\%) compared to those who have low self-ability (3\%). Strong self-ability will affect a person in behaving. The stronger the ability to use condoms, the better the behavior in usingcondoms. According to Jung (2013), the use of condomsincreased in subjects with high self-esteem.

An explanatory study conducted by Susilowati et al. (2015) usesa cross sectional approach and conducts Focus Group Discussion on dependent variableto obtain the result that there is a relation between self-efficacy with the use of condoms $(p<0.00)$, it described that a subject with high self-efficacy will use condoms consistently during sexual activity compared to subjects with low self-efficacy.

In accordance to PRECEDE PROCEED theory, self-efficacy is included in predisposing factor related to the behavior of the female commercial sex workers. Therefore, the predisposing factor related to the behavior of female commercial sex workers prevents them from sexually transmitted diseases and HIV/ AIDS, so it improves their quality of life.

\section{c. The relation of condoms availabi-}

lity with safe sexual behavior

There is a positive relationship between condoms availability with safe sexual behavior of female commercial sex workers, and the effect is statistically significant ( $\mathrm{b}=0.30 ; 95 \% \mathrm{CI}=0.36$ to $1.20, \mathrm{p}<0.001$ ). This is in line with the studyconducted by Arifianti et al. (2008) which was an explanatory studyusing the combination of quantitative and qualitative approaches or Triangulation Logic and the results show that most respondents have been able to provide condoms for every customer in order to always perform safe sex.The subjects also tried to convince the customers to use condoms although not all the customers want to use it.

Another study was conducted by Kismiyati et al. (2014). It was a qualitative study with in-depth interviews and the study result supports this study by the fact that condoms availability and condoms use in Tanjung Elmo Localization has been sufficient. Most of them have used condoms to prevent HIV/AIDS. The rate of failure of condoms in the transmission of sexually transmitted diseases and HIV/AIDS is only $2 \%$ if it is used consistently and properly.

Meanwhile, according to the study conducted by Sianturi (2013) using the 
same method as this study, it showed that there is a relationship between condoms availability with FCSW behavior in using condoms, because using condoms is one of the example ofsafe sex behavior in preventing sexually transmitted diseases and HIV/AIDS. Condoms availability around the localization area makes it easier to buy thecondoms in order to minimize the reluctance of customers to use condoms. Condoms availability will increase the use of condoms during sexual activity. The use of condoms will increase if condoms are always available and easy to get.

Kawangung's study (2012) combined both quantitative and qualitative study, similar to this study, the result showed that condoms availability contributes to the use of condoms. FCSW who can easily access thecondoms have 0.6 times of possibility to always use condoms at the last sexual activity compared to FCSW who find it difficult to get condoms. FCWS who get condoms esily also have 1.7 times of possibility to use condoms in the last one week compared to the FCSW who do not getcondoms easily. Safe sexual behavior to prevent IMS HIV/AIDS requires the use of condoms, therefore, high condoms availability is needed.

This study is also supported by a study conducted by Utami et al. (2016). It is a descriptive and cross-sectional study design. They stated that condoms availability is related to condoms user behavior. The availability of facilities and infrastructure will facilitate or accelerate an activity, in the sense that if the condoms is available in places where sexual activity is done, it will encourage someone to use it.

Based on the study conducted by Megaputri (2016) with logistic regression analysis method, it was found that condoms use was significantly related to condoms availability. Similar to the study in
Philippines, it is stated that the use of condoms is related to the condoms availability in sexual activities.

It can be concluded that condoms availability is related to safe sexual behavior of female commercial sex workers. If the condoms is available in their workplace, it will encourage them to use it as an effort to prevent sexually transmitted diseases and HIV/AIDS. Therefore, it will improve their quality of life. In accordance to the PRECEDE PROCEED theory used in this study, it is stated that condoms availability is included in the enabling factors associated with sexual behavior of female commercial sex workers.

\section{d. The relation of access to health services with safe sexual behavior}

There is a positive relationship between access to health services and safe sexual behavior in female commercial sex workers. With an easy access to health services, female commercial sex workers will use it maximally. This study is consistent with Ariani et al. (2015), which stated that female commercial sex workers used mobile sexually transmitted diseases services for genital or medical check ups. Pan et al. (2015) also stated that female commercial sex workers in Shanghai used the health services properly, they routinely take less than 12 months of HIV test.

Study by Hesketh et al. (2005) with 84 subjects sample of FCWS and using questionnaires as data collection instrument show that female commercial sex workers have accessed health services, 46 subjects havedone at least one medical check up, 37 of them came from prostitution that usually took place around the traffic lights and the other nine tookroutine check up. The medical check up was to check the pelvic and papsmear, sometimes syphilis check up, while the HIV test was not conducted unless they ask to. 
Journal of Epidemiology and Public Health (2018), 3(1): 60-71

https://doi.org/10.26911/jepublichealth.2018.03.01.05

Based on the descriptions presented above, the access to health services is associated with safe sexual behavior. If the access to health services is good, then sex workers will use it as self-check up, genital check up, blood test, and othersto prevent sexually transmitted diseases and HIV/AIDS that affect their health and improve their lives as sex workers. This is in accordance to the theory used in this study namely PRECEDE PROCEED theory.

\section{d. The relation of health personnel supports with safe sex behavior}

There is a positive relationship between the support of health personnel supports with safe sexual behavior of female commercial sex workers. This is in line with the study conducted by Kismiyati et al. (2014), it is stated that health personnel at Tanjung Elmo Localization were very supportive in terms of providing condoms, informing their subordinates to always use condoms, and conducting condoms monitoring every month in order to prevent HIV/AIDS diseasesso that sexual workers in Tanjung Elmo Localization can have safe sexual behavior.

This study is supported by the study conducted by Asnol (2016) which was qualitative study. It is stated that there is a support from the health personnel about the consistency in condoms use for HIV/AIDS prevention. The triangulation informant stated that the support of health personnel here is by doing health promotion such as counseling and socialization and also by providing the condoms.

In line with the study conducted by Christina et al. (2017) using Structural Equation Modeling (SEM) analysis which stated that the role of health personnel positively influences the condoms use behavior and it showed both direct and indirect effects. If the health personnel do their job well, then it can increase the habit of FCSW in using condoms, and vice versa, if the health personnel fail to do their job, then it will reduce the rate of condoms use.

Study conducted by Purnamawati (2013) showed that health personnel support the efforts to prevent sexually transmitted diseases, HIV and AIDS, such as counseling, free condoms distribution, blood test, and vaginal secretions to female commercial sex workers in the localization.

This study is also in line with the study conducted by Sianturi (2013) which indicated a meaningful relationship between health workers' support and the use of condoms by female commercial sex workers in sexual activity. It was by conducting counseling activities about the benefits of condoms regularly and continuously by health personnel to the female commercial sex workers, doing routine medical check up and providing condoms to FCSW in order to make them willing to use condoms as advised by health personnel. Health personnel greatly influence the behavior of female commercial sex workers by motivating the use of condoms in the implementation of safe sex.

It can be seen from the study conducted by Sianturi et al. (2012) and Sembiring (2012) thatthe effort of health personnel in preventing sexually transmitted diseases and HIV/AIDS has been good. The health personnel conducted screening every month. It was conducted in the second or third week in warung bebek localization. The efforts by the health personnel are also in accordance with Department of Health (2006) that sexually transmitted diseases prevention consists of two parts, namely primary and secondary. Primary prevention is the implementation of safe sexual behavior and the use of condoms. Meanwhile, secondary prevention is the treatment for patients who have sexually transmitted diseases. 
In accordance to the PRECEDE PROCEED theory in the reinforcing factor, the supports of health personnel are associated with safe sexual behavior of female commercial sex workers who will affect their health.Health education and counseling by health personnel can improve the knowledge of female commercial sex workers and make them aware of the importance of safe sexual behavior which can improve their quality of life by preventing sexually transmitted diseases and HIV/AIDS.

\section{e. The relation of peer's support with safe sexual behavior}

There is a positive relationship between peer's support and safe sexual behavior in female commercial sex workers. Demartoto et al. (2017) stated that peer's support to female commercial sex workers was highly necessary so that FCSW understandabout the reproduction health, with the guidance and supervision of condoms use, it can prevent the sexually transmitted diseases transmission.Peer's support in developing countries significantly improves the knowledge about HIV, reduces shared needles and increases thecondoms use.

This study is consistent with Purnamawati (2013) stating that peer's support can increase the use of condoms. Therefore, safe sexual behavior in high risk groups such as female commercial sex workers can prevent sexually transmitted diseases and, HIV/AIDS cases.

This study is supported by Kristianti's (2012) study which used both quantitative and qualitative approaches. The result showed that female commercial sex workers are supporting to always stay healthy and not to be infected by sexually transmitted diseases or HIV/AIDS. They said that their health was very important for their lives, because they still wanted to work for their living needs.The use of condoms in sexual activities should be consistenly done. The awareness of using the condoms for customers and female commercial sex workers is the important key in the consistency of condoms use. Consistent condoms use should also be supported by other FCSW, but the problem is that there are some customers who refuse to use the condoms.

Christina et al. (2017) stated that there are direct and indirect influences. Peer's support has a positive effect on condoms use behavior. If the peer support runs well,it will increase the habit of FCSW in using condoms.

Peer support in PRECEDE PROCEED is included in the reinforcing factor associated with safe sexual behavior of female commercial sex workers. Peer support will increase their understanding of safe sex and improve the quality of life.

\section{REFERENCES}

Ariani D, Mardiana, Ningrum DNA (2015). Perilaku Pencegahan Infeksi Menular Seksual pada Wanita Pekerja Seksual Kabupaten Tegal. Jurnal Kesehatan Masyarakat, 10(2): 160-168.

Arifianti NA, Harbandinah P(2008). Analisis Faktor-Faktor Penyebab Niat Wanita Pekerja Seks (WPS) Yang Menderita IMS Berperilaku Seks Aman (Safe Sex ) Dalam Melayani Pelanggan. Promosi Kesehatan, 3(2), 102-114.

Asnol UB (2016). Perilaku konsistensi waria yang bekerja di salon menggunakan kondom untuk pencegahan HIV dan AIDS di Kecamatan Sintang. Wawasan Kesehatan, 2(2): 25-50.

Budiman NA, Istiarti T, BM S (2008). Faktor-Faktor Yang Berhubungan Dengan Praktik Wanita Pekerja Seks (WPS) Jalanan Dalam Upaya Pencegahan IMS Dan HIV/AIDS Di Sekitar 
Journal of Epidemiology and Public Health (2018), 3(1): 60-71

https://doi.org/10.26911/jepublichealth.2018.03.01.05

Alun-Alun Dan Candi Prambanan Kabupaten Klaten. Jurnal Promosi Kesehatan Indonesia, 3(2), 120-126.

Budiono I (2012). Konsistensi Penggunaan Kondom Oleh Wanita Pekerja Seks/Pelanggannya. Jurnal Kesehatan Masyarakat, 7(2), 89-94.

Christina T, Novita A (2017). Pengaruh empat variabel terhadap perilaku penggunaan kondom wanita penjaja seks (WPS). Jurnal Ilmiah Kesehatan, 16(1), 1-12.

Demartoto A, Zunariyah S, Soemanto RB (2017). Pendidikan Sebaya Terstruktur Responsif AIDS. Surakarta: CV. Kekata Group.

Ford K, Wirawan DN, Reed BD, Muliawan P,Sutarga M (2000). AIDS and STD knowledge, condoms use and HIV/ STD infection among female sex workers in Bali, Indonesia. AIDS Care, 12(5): 523-534.

Hesketh T, Zhang J, Qiang DJ (2005). HIV knowledge and risk behavior of female sex workers in Yunnan Province, China: potential as bridging groups to the general population. AIDS Care, 17(8): 958-966.

Jung M (2013). Sexual Behavior and Condoms Use among Gay Men, Female Sex Workers, and Their Customers: Evidence from South Korea. PLoS ONE, 8(6): 2-9.

Kawangung VY (2012). Pengaruh Ketersediaan Kondom Terhadap Penggunaan Kondom Pada Seks Komersial Di Lokasi Batu 24 Dan Batu 8o Kabupaten Bintan Provinsi Kepri Tahun 2012, FKMUI, 2012.

Kismiyati H, Muh Syafar SN (2014). Jayapura The Behavior Of The Condoms Users Toward The Hiv And Aids Prevention Among The Sex Workers In Tanjung Elmo Jayapura Regency Kismiyati H, Muh Syafar, Sudirman
Natsir Makassar Alamat Korespondensi: Kismiyati Fakultas Kesehatan Masyarakat Univer.

Komisi Penanggulangan AIDS Kota Surakarta (2017). Studi Pendahuluan. Surakarta

Kristianti S (2012). Dukungan WPS dan Teman Pelanggan terhadap Penggunaan Kondom pada Pelanggan WPS di Semampir Kediri.Jurnal STIKES, 5(2), 144-154.

Megaputri P (2016). Negosiasi dan Determinan Pemakaian Kondom oleh Pekerja Seks di Kota Denpasar. Public Health and Preventive Medicine Archive, 4, 3-11.

Nyagero J, Wangila S, Kutai V, Olango S (2012). Behavior change and associated factors among female sex workers in Kenya. The Pan African Medical Journal, 13(1): 16.

Pan R, Mao L, He N, Zhang J, Chen K, Liao, C, De Wit J (2015). Factors associated with establishment-based female sex workers accessing health care services in Shanghai. AIDS Care-Psychological and Socio-Medical Aspects of AIDS/ HIV, 27(6): 688-692.

Purnamawati D (2013). Perilaku Pencegahan Penyakit Menular Seksual di Kalangan Wanita Pekerja Seksual Langsung. Jurnal Kesehatan Masyarakat Nasional, 7(11): 514-521.

Ritcher M (2013). Characteristics , sexual behavior and access to health care services for sex workers in South Africa and Kenya, 26(2), 1-190.

Sembiring E, Sembiring R (2012). The Influence of Predisposing, Enabling and Reinforcing Factors Related to Sexually.

Sianturi SA (2013). Hubungan Faktor Predisposisi, Pendukung, Dan Penguat Dengan Tindakan Penggunaan Kondom Pada WPS Untuk Pencegahan 
HIV/AIDS Di Kabupaten Serdang Bedagai. Jurnal Precure, 1(1): 1-7.

Sirait LM, Sarumpaet S (2013). Hubungan Komponen Health Belief Model (HB) Dengan Penggunaan Kondom Pada Anak Buah Kapal (ABK) Di Pelabuhan Belawan The Relationship Between Health Belief Model Components And The Use Of Condoms Among Ship Crews At Belawan Seaport. Jurnal Precure, 1(4): 43-49.

Susilowati, Erna SK(2015). Faktor Predisposisi Dan Pemungkin Perilaku Penggunaan Kondom Pada Pelanggan WPS Semampir Kediri, 3(2): 9-18.

Utami YS, Cahyo K, Indraswari R (2016). Faktor-Faktor Yang Berhubungan
Dengan Perilaku Penggunaan Kondom Pada Klien Wanita Pekerja Seks (Wps) Dalam Upaya Pencegahan Infeksi Menular Seksual (Ims) Di Kelurahan Bandungan. Jurnal Kesehatan Masyarakat, 4(3): 1113-1120.

Widodo E (2009). Praktik Wanita Pekerja Seks (WPS) Dalam Pencegahan Penyakit Infeksi Menular Seksual (IMS) Dan HIV\&AIDS Di Lokalisasi Koplak, Kabupaten Grobogan. Jurnal Promosi Kesehatan Indonesia, 4(2): 94-102.

Wulandari YA, Suryani N, Poncorini E (2016). Health Belief Model: Health Preventive Behavior of Sexually Transmitted Infection in Female Sex Workers in Surakarta, 1: 71-79. 